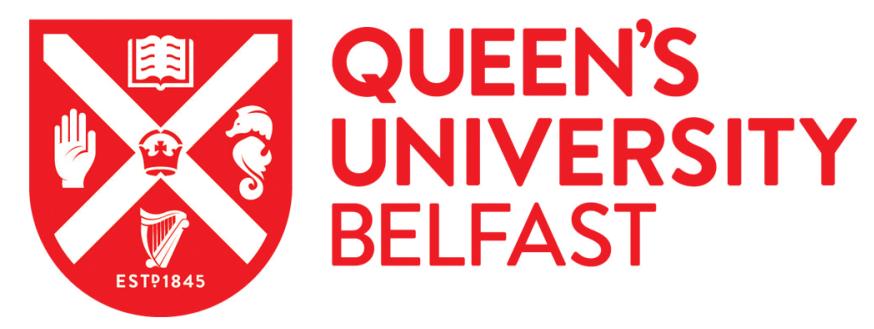

\title{
Why do national court judges refer to human rights treaties?: A comparative international law analysis of CEDAW
}

McCrudden, C. (2015). Why do national court judges refer to human rights treaties?: A comparative international law analysis of CEDAW. American Journal of International Law, 109(3), 534-550.

https://doi.org/10.5305/amerjintelaw.109.3.0534

Published in:

American Journal of International Law

Document Version:

Publisher's PDF, also known as Version of record

Queen's University Belfast - Research Portal:

Link to publication record in Queen's University Belfast Research Portal

Publisher rights

(c) 2015 American Journal of International Law

\section{General rights}

Copyright for the publications made accessible via the Queen's University Belfast Research Portal is retained by the author(s) and / or other copyright owners and it is a condition of accessing these publications that users recognise and abide by the legal requirements associated with these rights.

Take down policy

The Research Portal is Queen's institutional repository that provides access to Queen's research output. Every effort has been made to ensure that content in the Research Portal does not infringe any person's rights, or applicable UK laws. If you discover content in the Research Portal that you believe breaches copyright or violates any law, please contact openaccess@qub.ac.uk. 
Why Do National Court Judges Refer to Human Rights Treaties? A Comparative International Law Analysis of CEDAW

Author(s): Christopher McCrudden

Source: The American Journal of International Law, Vol. 109, No. 3 (July 2015), pp. 534-550

Published by: American Society of International Law

Stable URL: http://www.jstor.org/stable/10.5305/amerjintelaw.109.3.0534

Accessed: 11-01-2016 14:09 UTC

Your use of the JSTOR archive indicates your acceptance of the Terms \& Conditions of Use, available at http://www.jstor.org/page/ info/about/policies/terms.jsp

JSTOR is a not-for-profit service that helps scholars, researchers, and students discover, use, and build upon a wide range of content in a trusted digital archive. We use information technology and tools to increase productivity and facilitate new forms of scholarship. For more information about JSTOR, please contact support@jstor.org. 


\title{
WHY DO NATIONAL COURT JUDGES REFER TO HUMAN RIGHTS TREATIES? A COMPARATIVE INTERNATIONAL LAW ANALYSIS OF CEDAW
}

\author{
By Christopher McCrudden*
}

\section{INTRODUCTION}

Comparative international law promises to bring fresh attention to the similarities and differences in how international law is understood and approached at the domestic level. ${ }^{1} \mathrm{Com}-$ parative international human rights law applies this focus to similarities and differences in the ways that international human rights law is, for example, interpreted at the domestic level by courts. $^{2}$

As a contribution to this emerging field, I conducted a limited study of the domestic judicial interpretation of one core international human rights convention, the Convention on the Elimination of All Forms of Discrimination Against Women (CEDAW) ${ }^{3}$ In an attempt to test the utility of a comparative international law approach, an analysis was conducted of 325 national judicial decisions across fifty-five jurisdictions, in which CEDAW was referred to in the report of the case, including the arguments made to, or the reasoning of, the court (subsequently referred to as "the dataset").

A more detailed description of this study, the methodology I adopted in conducting the study, a justification of that methodology including its focus on the domestic judicial use of CEDAW, the important limitations of the methodology I adopted, and the detailed findings of the study will all be published as a chapter in a separate Colloquium volume, Comparative

* Fellow of the British Academy; Professor of Equality and Human Rights Law, Queen's University Belfast; William W. Cook Global Professor of Law, University of Michigan Law School; Fellow, Wissenschaftskolleg zu Berlin (2014-15). The author thanks Veronika Fikak, Benedict Kingsbury, Christoph Möllers, Daniel Peat, Steve Ratner, Anthea Roberts, Mila Versteeg, participants at the Sokol Colloquium on Comparative International Law at the University of Virginia, participants at a seminar at Humboldt University, and several anonymous referees, for helpful comments and suggestions on earlier drafts. Several colleagues also assisted in attempting to locate relevant case law in Japan, the People's Republic of China, and Russia. I am exceptionally grateful to Gleb Bogush, Akiko Ejima, Nico Howson, Benedict Kingsbury, Mark West, and Alex X. Zang.

${ }^{1}$ Anthea Roberts et al., Conceptualizing Comparative International Law, in COMPARATIVE INTERNATIONAL LAW (Anthea Roberts et al. eds., forthcoming).

${ }^{2}$ See Christopher McCrudden, Comparative International Law and Human Rights, in COMPARATIVE INTERNATIONAL LAW, supra note 1.

${ }^{3}$ Convention on the Elimination of All Forms of Discrimination against Women, opened for signature Dec. 18 , 1979, 1249 UNTS 13, 19 ILM 33. See, in particular, WOMEN's HUMAN RIGHTS: CEDAW IN INTERNATIONAL, REGIONAL AND NATIONAL LAW (Anne Hellum \& Henriette Sinding Aasen eds., 2013) [hereinafter WOMEN'S HUMAN RIGHTS]; THE UN CONVENTION ON THE ELIMINATION OF ALL FORMS OF DISCRIMINATION AGAINST WOMEN: A COMMENTARY (Marsha A. Freeman et al. eds., 2012); THE WOMEN's CONVENTION TURNED 30: ACHIEVEMENTS, SETBACKS, AND PROSPECTS (Ingrid Westendorp ed., 2012). 
International Law. ${ }^{4}$ This chapter should be of interest to future scholars attempting to conduct any similar inquiry, particularly those interested in considering how to test hypotheses and predictions emerging from the field of comparative international human rights law.

Although I do not seek to go into detail here on these findings, a brief sketch of them is necessary for understanding the analysis conducted in the current article. There are four important empirical findings from this study. First, references to CEDAW are seldom more than cursory and are usually to be found combined with lists of other international instruments. CEDAW is infrequently singled out for special mention and even less frequently subject to substantive interpretation.

Second, although there are significant differences between jurisdictions in nonsubstantive areas (for instance, in how CEDAW is received into the national legal and judicial systems, in the techniques of interpretation applied, and in the legal status of CEDAW at the national level), these differences appear to have relatively little effect on the substantive interpretation of CEDAW.

Third, although there are prominent examples of cases in which national courts adopt substantively different interpretations of CEDAW, the evidence from the dataset shows a remarkable absence of divergence across jurisdictions as to the substantive meaning of CEDAW. This is the case not only with regard to the results that the courts arrive at, but also in the conception of rights incorporated in CEDAW (to whom are obligations owed, by whom, and with what limitations?). This finding is significant but the implications of this finding should not be exaggerated; it arises partly because they are relatively few instances in which the same issue arises in different jurisdictions. The lack of disagreement may signal that the comparative case law available on any particular substantive issue is relatively thin.

Fourth, courts did not tend to refer to the interpretations of CEDAW by other foreign domestic courts, and little transnational judicial dialogue takes place in the interpretation of CEDAW by national judges, even where engagement with foreign judicial sources is otherwise commonplace in the interpretation of national constitutional and statutory law, and even in cases where there are directly relevant foreign judgments.

The most difficult questions, assuming these findings are correct, are how and why these similarities and differences come about. In the present article, I present a preliminary analysis of these findings, tackling the difficult question of how to explain this pattern of use, and I tentatively suggest explanations. My provisional conclusion is that observable similarities and differences result, at least in part, from the functions that international human rights law fulfills in domestic jurisdictions, and that these functions may differ from the role that international human rights law plays at the international level.

\section{ANALYSIS AND A PROVISIONAL EXPLANATION}

This study challenges several current explanations of the domestic use of international law by domestic courts: that the interpretation of international law is likely to show significant variation domestically; ${ }^{5}$ that domestic courts act as agents of the international legal order; ${ }^{6}$ and that

\footnotetext{
${ }^{4}$ COMPARATIVE INTERNATIONAL LAW, supra note 1.

${ }^{5}$ See, e.g., David Kennedy, The Disciplines of International Law and Policy, 12 LEIDEN J. INT'L L. 9, 17 (1999); Karen Knop, Here and There: International Law in Domestic Courts, 32 N.Y.U. J. INT'L L. \& POL. 501, 503, 506
} 
domestic courts seek to shape international legal approaches through their domestic interpretations, in order to serve national interests. ${ }^{7}$ None of these suggestions drawn from recent scholarship is unequivocally supported by my study of the judicial use of CEDAW in national level cases. Indeed, the pattern of use is substantially different from what might have been predicted in each case. We need, therefore, to present additional or alternative explanations for the pattern of domestic use of international human rights law that replace, supplement, or complement these explanations.

\section{Domestic Courts and International Law}

The evidence I present in Comparative International Law indicates that domestic judges are primarily domestic actors who use CEDAW in order to advance domestic goals. Thus, although in legal theory international law may provide the "overarching normative framework" within which national courts operate, ${ }^{8}$ that is often not how it seems, reading the judgments. In terms of Eyal Benvenisti's typology, ${ }^{9}$ drawing from the evidence of the use of CEDAW, domestic courts see themselves as domestic players using international law strategically, but there is little evidence that they see themselves as agents or trustees of international law. They do not primarily see themselves, therefore, as seeking to achieve the goal of advancing international law as such (what Anthea Roberts has termed national courts as "impartial law enforcers" of international law ${ }^{10}$ ). Nor do they appear to see themselves as agents of a domestic community seeking to shape international legal approaches to suit the preferences of their own state (what Roberts has termed national courts as "partial law creators" of international law $\left.{ }^{11}\right)$. The strategic goals they seek to further are mostly institutional rather than national, supporting the recent findings by Aust, Rodiles, and Staubach. ${ }^{12}$ The key word is mostly. There are examples where the relevant court does appear more in the guise of an "agent" of international law. ${ }^{13}$

In general, however, my analysis coheres with that of Paul Stephan. Echoing Stephan's more general analysis, the evidence regarding CEDAW indicates that the national courts "have interests of their own, shaped by the incentives motivating those who work in those institutions and

(2000); see generally Anthea Roberts, Comparative International Law? The Role of National Courts in Creating and Enforcing International Law, 60 INT'L \& COMP. L.Q. 57 (2011).

${ }^{6}$ See, e.g., ANDRÉ NOlLKAEMPER, NATIONAL COURTS AND THE INTERNATIONAL RULE OF LAW 8 (2011).

7 See Eyal Benvenisti, Judicial Misgivings Regarding the Application of International Law: An Analysis of Attitudes of National Courts, 4 EUR. J. INT'L L. 159, 161 (1993).

${ }^{8}$ NOLLKAEMPER, supra note 6, at 1.

${ }^{9}$ Eyal Benvenisti, Reclaiming Democracy: The Strategic Uses of Foreign and International Law by National Courts, 102 AJIL 241 (2008).

${ }^{10}$ Roberts, supra note 5, at 68.

${ }^{11} \mathrm{Id}$.

${ }^{12}$ Helmut Philipp Aust, Alejandro Rodiles \& Peter Staubach, Unity or Uniformity? Domestic Courts and Treaty Interpretation, 27 LEIDEN J. INT'L L. 75 (2014).

${ }^{13}$ Pant v. Nepal Government, Writ No. 917 of 2064, 138 I.L.R. 500 (S. Ct. Nepal 2007). The Court said: "We . . should internalize the international practices in regard to the enjoyment of the right of an individual . . .." Id. at 528. The Court continued: "Otherwise, our commitment to the human rights will be questioned internationally, if we ignore the rights of such people only on the ground that it might be a social stigma." Id. Even here, however, the Court was intent on creating a degree of distance between itself and the international community. It stressed the need to "chang[e] world society and practices of respecting the rights of minorit[ies] gradually." Id. (emphasis added). 
the institution's design." ${ }^{14}$ My evidence also supports a modest generalization of Neha Jain's conclusion regarding the Indian Supreme Court's citation of international law. Discussing that particular court, she suggests that "the Supreme Court has used international law in the pursuit of primarily domestic goals." ${ }^{15}$ Her description appears to describe accurately the approach taken by domestic courts more generally in the context of citation of CEDAW. Viewing the evidence presented previously through this lens seems to provide a more satisfying approach to explaining several critical findings.

\section{Substantive Interpretative Divergence}

Recent international law scholarship has suggested, contrary to the longstanding assumptions on which international law often proceeded in the past, ${ }^{16}$ that the interpretation of international law at the domestic level is likely to show significant divergence from country to country and from region to region. ${ }^{17}$ This argument mirrors similar arguments concerning the interpretation of international law at the international level, where significant differences in substantive interpretations of the same text have been observed. The latter phenomenon has been termed "fragmentation." 18

According to Sally Merry, the domestic reception of international legal norms (what she calls "vernacularization") "falls along a continuum depending on how extensively local cultural forms and practices are incorporated into imported institutions." ${ }^{19}$ Using her analytical continuum of "vernacularization," she compares jurisdictions based on such factors as whether international human rights law has been "rejected"; whether it has been "ignored"; whether it has been "subverted" (by which Merry means "seized and transformed into something quite different from the transnational concept, out of the reach of the global legal system but nevertheless called by the same name"); ${ }^{20}$ whether a process of "replication" is to be found in which "the imported institution remains largely unchanged from its transnational prototype" and any adaptation is "superficial and primarily decorative"; or whether "hybridization" can be identified, meaning that there is "a process that merges imported institutions and symbols with local ones, sometimes uneasily." 21

${ }^{14}$ Paul B. Stephan, The Structure of Courts and International Lawmaking-Explaining Judicial Conflict, in COMPARATIVE INTERNATIONAL LAW, supra note 1. Where I part company with Stephan, however, is that I do not seek to suggest that the way the courts behave is due to the structuring of the courts' mechanisms by political actors. I leave open, therefore, the extent to which the courts in this context act as agents of national political actors, but my intuition is that this is, in the main, not what is happening in the cases I have considered.

${ }^{15}$ Neha Jain, The Democratizing Force of International Law: Human Rights Adjudication by the Indian Supreme Court, in COMPARATIVE INTERNATIONAL LAW, supra note 1.

${ }^{16}$ Hersch Lauterpacht, Decisions of Municipal Courts as a Source of International Law, 10 BRIT. Y.B. INT'L L. 65, 93 (1929) (identifying national courts as "the trusted mouthpieces of international law”); id. at 95 (“[I]nternational law is the only branch of law containing identical rules professedly administered as such by the courts of all nations.").

17 See, e.g., Kennedy, supra note 5, at 17; Knop, supra note 5, at 503, 506; see generally, Roberts, supra note 5.

${ }^{18}$ See, e.g., Martti Koskenniemi \& Päivi Leino, Fragmentation of International Law? Postmodern Anxieties, 15 LEIDEN J. INT'L L. 553 (2002).

${ }^{19}$ Sally Engle Merry, Transnational Human Rights and Local Activism: Mapping the Middle, 108 AM. ANTHROPOLOGIST 38, 44 (2006).

${ }^{20} \mathrm{Id}$. at 40 .

${ }^{21} \mathrm{Id}$. at 44 . 
Susanne Zwingel has suggested that domestic reception of international norms is likely to result in significant differences from place to place, and that previous assumptions that such norms would lead to greater homogenization are exaggerated. ${ }^{22}$ As Zwingel puts it, "universal principles, when applied to particular contexts, inevitably take on different forms." 23 There has long been a critique of how international law has been seen by scholars to operate in practice at the domestic level. The criticism is that the process has been seen as too top-down, with international law being received at the domestic level somewhat passively and with domestic actors rarely exercising independent agency in (re)constructing international law in the process of its domestic reception. ${ }^{24}$ Some seek to develop a more neutral language of engagement between the domestic and the international, one in which a more syncretic approach is taken, when a different norm emerges out of the contact between the exported norm and the indigenous norm. Based on this, we might have predicted, therefore, that an equivalent type of "fragmentation" is occurring at the national level as is said to have taken place at the international level, and that we could expect a significant degree of divergence in the substantive interpretation of the Convention at the national level. ${ }^{25}$

This does not seem to be the case in the context of CEDAW. There are clear examples of where appeals to CEDAW norms have been marginalized and ignored, ${ }^{26}$ but (importantly) few clear examples of outright rejection, or of subversion, or (more surprisingly, perhaps) of hybridization in the substantive interpretation of the CEDAW norms at the judicial level. (Of course, what constitutes "subversion" and "hybridization" is somewhat in the eye of the beholder. ${ }^{27}$ ) These seem to be entirely missing, at least in so far as the domestic judicial interpretation of

22 Susanne Zwingel, How Do Norms Travel? Theorizing International Women's Rights in Transnational Perspective, 56 INT'L STUD. Q. 115, 121 (2012).

${ }^{23} \mathrm{Id}$. at 126.

${ }^{24} I d$. at 118 .

25 This is similar to the hypothesis articulated by Stephan, supra note 14 ("National courts will demonstrate a significant variation in claims about international law."). See also Aust, Rodiles \& Staubach, supra note 12.

${ }^{26}$ E.g., Malkani v. Secretary of the Ministry of Home Affairs, Writ Petition No. 3192 of 1992 (S. Ct. Bangl. 1997) (described in ASIA PACIFIC FORUM ON WOMEN, LAW AND DEVELOPMENT, A DIGEST OF CASE LAW ON THE HumAN RightS OF Women (Asia Pacific) 9-11 (2003)); Peter v. Ministry of Home Affairs, No. 1379 of 2048, 11 N.K.P. 2048 at 749 (Nepal 1992) (described in FORUM FOR WOMEN, LAW AND DEVELOPMENT, IMPACT OF EXISTING DISCRIMINATORY CITIZENSHIP LAW ON WOMEN AND CHILDREN IN NEPAL 61-62 (2006)).

${ }^{27}$ For example, the Constitutional Court of Turkey was asked to consider a legislative provision that required women to adopt the name of their husbands on marriage: see Esas No. 2009/85, Karar No. 2011/49 (CUMA, Resmî Gazete, Sayı: 28091) [Official Newspaper, No. 28091] (Turk. 2011). CEDAW was interpreted as permitting the legislature to use its margin of appreciation on the basis of local historical and political reasons. For the Turkish litigant seeking not to use her husband's last name the court subverted CEDAW. Another example that comes close to subversion relates to Japan. Dana Zartner has argued that "Japanese courts assume that the meaning, scope, and effect of human rights provisions under international human rights law are the same as those under the Japanese Constitution." DANA ZARTNER, COURTS, CODES, AND CUSTOM: LEGAL TRADiTION AND STATE POLICY TOWARD INTERNATIONAL HUMAN RIGHTS AND ENVIRONMENTAL LAW 243 (2014) (citing YUJI IWASAWA, INTERNATIONAL LAW, HUMAN RIGHTS LAW AND JAPANESE LAW: THE IMPACT OF INTERNATIONAL LAW ON JAPANESE LAW 243 (1998)). In X1 and X2 v. Government of Japan, a Japanese court, in deciding that a provision of the Civil Code which prohibited women from remarrying for 180 days after divorce, did not violate CEDAW, assumed that CEDAW's provisions were no stricter than the Japanese Constitution. Hiroshima Kōtō Saibansho [Hiroshima High Ct.] Nov. 28, 1991, 1406 HANREI JiHŌ [HANJI] 3 (Japan). 
CEDAW is concerned. Anne Bayefsky's conclusion regarding the use of CEDAW in the Canadian courts seems to be generalizable: "Where courts are inclined to come to conclusions incompatible with the Convention, they will simply ignore it." 28

It may be that courts cite CEDAW mostly when they want to draw support from it, but when they want to disagree with a particular reading of CEDAW, they just marginalize and ignore it, rather than reinterpret, subvert, or hybridize. The Lesotho High Court, for example, in upholding customary law rights relating to male succession to chieftainship, relied on the fact that, in acceding to CEDAW, the government had entered reservations, as it was permitted to do under CEDAW, which specifically excluded matters concerning customary practices relating to succession to the throne and to chieftainship. The Court referred to CEDAW and the Government's reservation as a reason why it should not interfere with the Executive and the Legislature in this matter. ${ }^{29}$ The international remains important, but in these cases to defend the status quo rather than change it.

\section{An Artefact of the Methodology?}

It is arguable, however, that the finding of relative homogeneity of domestic interpretation is an artefact of the limits on my original model for selection of cases. Only looking at cases where CEDAW has been cited, rather than where it could have been cited but was not, is likely to lead to a skewed picture as to the extent to which national courts disagree with CEDAW or with particular interpretations of CEDAW by others. The methodology of looking at cases where CEDAW is cited, rather than not cited, might result in a blind spot as to the degree to which there is disagreement and divergence among national judges. ${ }^{30}$

There is another possible explanation for the absence of apparent divergence, which again has to do with the methodology I adopted. There was significant substantive divergence on three issues: the implications of the requirement in CEDAW that "special measures" should be "temporary," the application of CEDAW to customary inheritance laws, and the appropriate metaprinciple which should influence the interpretation of the CEDAW provisions. ${ }^{31}$ The first two of these issues have generated a relatively "thick" comparative jurisprudence, giving some weight to an argument that significant differences in substantive interpretation may be apparent only when there is jurisprudence available in which the same or similar issues arise in a sufficient number of different jurisdictions. It can be argued that the relative paucity of such jurisprudence camouflages the extent of divergence. On the other hand, the relative absence of diverging interpretation in the context of applications of CEDAW to rape and divorce among others - in which a relatively thick comparative jurisprudence does exist but there is still minimal divergence- - urges caution in rushing too swiftly to a conclusion that my results are simply an artefact of the absence of a sufficiently dense comparative jurisprudence.

${ }^{28}$ Anne F. Bayefsky, General Approaches to Domestic Application of Women's International Human Rights Law, in HUMAN RigHTS OF WOMEN: NATIONAL AND INTERNATIONAL PERSPECTIVES 351, 365 (Rebecca J. Cook ed., 1994). For an equivalent conclusion regarding Chinese courts, see Congyan Cai, International Law, Domestic Courts, and the Rise of China, in COMPARATIVE INTERNATIONAL LAW, supra note 1.

${ }^{29}$ Masupha v. Senior Resident Magistrate for the Subordinate Court of Berea, L.S.H.C. 9 [58] (Lesotho 2013).

${ }^{30}$ If they do that, they might just ignore CEDAW, and this is perhaps borne out by the absence of any citations to CEDAW in the Chinese courts.

${ }^{31}$ McCrudden, supra note 2. 


\section{CEDAW as an International Norm}

My analysis does not suggest that CEDAW is treated as simply equivalent to national norms (domestic or foreign) or that the international legal status of CEDAW is simply ignored. AnneMarie Slaughter has long shown that an important set of explanations for how international law has been incorporated domestically has to do with such issues as the identity of the judges, the institutional framework and location within which they operate, their connectedness to global networks, and the constraints of the ideas and practice available to them in their discursive community. ${ }^{32}$ Importantly, for our purposes, Merry distinguishes domestic translators of international legal norms into the domestic context who "may have greater interest in the source ... of the transaction" from those who have "greater interest in ... the target of the transaction." 33 She continues: "[ $\mathrm{t}$ ] ranslators committed to the target produce more hybrid transplants whereas those closer to the source create replicas." ${ }^{4}$ The fact that we find few hybrid transplants in the CEDAW dataset suggests, based on Merry's suggestion, that there is indeed "greater interest" in the source than the target, and the source is, of course, international.

My evidence suggests that CEDAW's status as an "organ of the international community" is a critical reason why it is useful in addressing "primarily domestic goals." ${ }^{35}$ There appears to be a strong desire for domestic courts to emphasize that CEDAW contains norms that are (1) international (not just transnational or comparative) as well as (2) relatively static in their meaning (rather than subject to shifting meanings with a significant role for domestic interpretation in shaping that meaning).

This appears to be because of an important function that CEDAW plays at the domestic level. Promoting an external, static, and top-down understanding of international law means that it can be drawn on in ways and for purposes that a flexible and bottom-up understanding of international law, one in which the domestic court accepts that it has considerable latitude in the meaning of the international legal provision, would be less likely to support. In other words, CEDAW appears to be useful to domestic courts in particular where the court can present it as clear, external, and authoritative. As Merry has observed more generally, CEDAW's "regulatory strength depends on the cultural legitimacy of the international process of consensus building and related social movements to define social justice in these terms." ${ }^{36}$ CEDAW is a "form of global legality that depends deeply on its texts . . . for the production of cultural meanings associated with modernity and the international." 37 The domestic court has an active role in translating the norm, but it prefers to present this norm as top-down and its own role as somewhat passive.

32 ANNe-Marie Slaughter, A NeW WOrld Order 65-103 (2004) [hereinafter Slaughter, A NEW WORLD ORDER]; Anne-Marie Slaughter, A Global Community of Courts, 44 HARV. INT'L L.J. 191 (2003) [hereinafter Slaughter, Global Community]; Anne-Marie Slaughter, Judicial Globalization, 40 VA. J. INT'L L. 1103 (2000) [hereinafter Slaughter, Judicial Globalization]; Anne-Marie Slaughter, A Typology of Transjudicial Communication, 29 U. RICH. L. REV. 99 (1994) [hereinafter Slaughter, Typology].

${ }^{33}$ Merry, supra note 19 , at 40 .

${ }^{34} \mathrm{Id}$. at 48.

${ }^{35}$ Neha Jain appears to deny this. Jain, supra note 15 . Although, in general, my analysis is similar to Jain's, I disagree that this aspect of her analysis can be generalized beyond India.

${ }^{36}$ Sally Engle Merry, Constructing a Global Law_Violence against Women and the Human Rights System, 28 L. \& SOC. INQUIRY 941, 941 (2003).

${ }^{37}$ Id. at 973 . 
As a result, there is little evidence of the adoption of discourse-based approaches to the interpretation of CEDAW, in which relatively open-ended international human rights standards provide the opportunity for contested views to be openly debated and argued about, and where human rights norms are seen as continually reinvented and resolutions are at best temporary and provisional. That approach would simply not fulfill the function that domestic courts appear to need CEDAW to play.

In the judicial context, the international norm may not cause the judge to act in a particular way, but it gives the judge a way of grounding what they want to do in something beyond the judge's subjective views; to do this successfully, the judge has an incentive to make the international norm seem less malleable. Some further support for this suggestion may be drawn (by analogy) from Katerina Linos's recent study of the way that politicians like to reference how their ideas reflect international norms or practices adopted elsewhere and are therefore mainstream rather than idiosyncratic. ${ }^{38}$

There are several examples from the dataset. ${ }^{39}$ In supporting affirmative action provisions benefitting women in elections, the Indonesian Constitutional Court draws on CEDAW's support for affirmative action as representing developing international opinion, and regards this as a positive reason why domestic law should be interpreted to permit it also. ${ }^{40}$ In deciding that the marriage of a minor under the age of sixteen could not be the basis of a residence permit in light of the best interests of the child and other human rights considerations (including CEDAW), the Finnish Supreme Administrative Court rejected the more culturally relativistic approach of the lower court, in favor of an approach that was more universalistic, because this was the international standard. ${ }^{41}$ In deciding whether Kenyan courts could rely on international law to resolve succession disputes, the Kenyan Court of Appeal emphasized the international dimension in interpreting a provision of domestic law. In adopting this provision, " $[\mathrm{t}]$ he country was moving in tandem with emerging global culture, particularly on gender issues." 42 When American courts want to move against female genital cutting, it appears important to demonstrate (using CEDAW) that this move has international support. ${ }^{43}$ When the Indian Supreme Court engages in an intensive campaign against gender discrimination, it appeared to be important to it to stress that "the cry for equality and equal status . . . is not restrictive to any particular country but world over with variation in degree only." ${ }^{44}$ When the Egyptian Supreme Constitutional Court engages with the right to marry, it appears to be

\footnotetext{
${ }^{38}$ Katerina Linos, How to Select and Develop International Law Case Studies: Lessons from Comparative Law and Comparative Politics, in COMPARATIVE INTERNATIONAL LAW, supra note 1.

39 See also Ferneley v Boxing Auth. of New South Wales (2001) 115 FCR 306 (Austl.); Tōkyō Kōtō Saibansho [Tokyo High Ct.] Dec. 22, 2000, 796 Rōdō Hanrei 5 (Japan) (Shiba Shinyo Kinko case).

${ }^{40}$ Putusan No. 22-24 PUU-VI/2008 (Const. Ct. Rep. Indon.).

${ }^{41}$ A v. Directorate of Finnish Immigration, 5.12.2005/3219, KHO:2005:87, ILDC 594 (Sup. Admin. Ct. 2005) (Fin.). "When considering the provisions of international treaties . . cultural background was not a justification for taking a child to a third country, to which she had no ties, and marrying her off to a person whom she had not seen since her early childhood." Id.

${ }^{42}$ Rono v. Rono \& Another, (2005) 1 K.L.R. 803, 813 (Kenya).

${ }^{43}$ Boureslan v. Aramco, 857 F.2d 1014 (5th Cir. 1988); Abankwah v. I.N.S., 185 F.3d 18 (2d Cir. 1999); Bah v. Mukasey, 529 F.3d 99 (2d Cir. 2008).

${ }^{44}$ Hariharan v. Reserve Bank of India, (2000) 2 S.C.C. 228 (India).
} 
important to stress that the right to marry is protected both by Islamic Shari'a and by international instruments, including CEDAW. ${ }^{45}$

\section{Domestic Legal Status of CEDAW}

In seeking explanations for the relative absence of divergence, an alternative explanation is plausible, however. It may be that where reliance on CEDAW is not compulsory, it is easier to ignore CEDAW and not cite it than it is to cite it and then interpret it into a hybrid transplant. Domestic courts may be more likely to contest an interpretation of CEDAW by others when they have to engage with an international law norm. Some of the prominent cases that Stephan cites, for example, where a domestic court deliberately resists the position taken by an international court, seem to fall into this category. ${ }^{46}$ If courts do not have to engage with international legal norms, and their interest is really only in domestic application rather than international influence, they are likely to have less incentive to invoke CEDAW only to qualify it, disagree with it, or try to shift its interpretation.

This possibility bring us to the critical question of the possible effect of the national legal status of CEDAW, and the effect of that legal status on the pattern of use and non-use I have described. In this context, the legal status accorded to CEDAW can be regarded as an indication of how far the court considers that it "must" engage with CEDAW. To the extent that domestic courts adopt different substantive interpretations, or are less willing to cite CEDAW at all, it might be supposed that these differences reflect the different legal status accorded by states to human rights conventions. ${ }^{47}$ We might have predicted that states that regard ratified conventions as having direct legal effect will engage more intensively with CEDAW than states that require ratified conventions to go through some further domestic legal process (usually a legislative procedure of enactment) before a convention can be given domestic legal effect. ${ }^{48}$

There is, indeed, some evidence of this occurring. Courts do treat the question of the domestic legal status of CEDAW and whether it is legally binding as important. ${ }^{49}$ The (absence of) domestic legal status being accorded to CEDAW is more likely to be used, in the latter context,

${ }^{45}$ Case No. 23 of the 16th Judicial Year/1995/Supreme Constitutional Court (Egypt).

46 Compare HCJ 7957/04, Mara'abe v. Prime Minister of Israel 60(2) PD 477 [2005] (Isr.), with Legal Consequences of the Construction of a Wall in the Occupied Palestinian Territory, Advisory Opinion, 2004 I.C.J. 136 (July 9); compare Sanchez-Llamas v. Oregon, 548 U.S. 331 (2006), and Medellín v. Texas, 552 U.S. 491 (2008), with Case Concerning Avena and Other Mexican Nationals (Mex. v. U.S.), 2004 I.C.J. 12 (Mar. 31).

${ }^{4}$ See, e.g., Mila Versteeg, Law Versus Norms: The Impact of Human Rights Treaties on Constitutional Rights (Va. Pub. Law \& Legal Theory Research Paper Series, No. 2014-02), available at http://papers.ssrn.com/sol3/papers. cfm?abstract_id=2360814 (describing the impact of human rights treaties as dependent on whether a state has a monist or dualist system).

${ }^{48}$ ERIC A. POSNER \& AlAN O. SyKes, ECONOMIC FOUNDATIONS OF INTERNATIONAL LAW 4 (2013).

${ }^{49}$ Courts refer to CEDAW as binding law ("duty") in the following cases: Halagueña v. Philippine Airlines, Inc., G.R. No. 172013, 602 S.C.R.A. 297 (Phil. 2009); Romualdez-Marcos v. Commission on Elections, G.R. No. 119976, 248 S.C.R.A. 300 (Phil. 1995); Constitutional Court [Const. Ct.], 98Hun-Ma363, Dec. 23, 1999, (11-2 KCCR 770) (S. Kor.); Supreme Court [S. Ct.], 2002Da1 178, July 21, 2005 (S. Kor.); Awop v. Lapenmal, VUIC 2 (Malekula I. Ct. 2007) (Vanuatu); Gerechtshof's-Gravenhage, NJF 2010, 113 m.nt Drewes en van Hellemondt (Wichmann/Ministerie van Volksgezondheid, Welzijn en Sport) (Neth. 2010); HR, JB 2010, 115 m.nt Schutgens en Sillen (Ministerie van Binnenlandse Zaken en Koninkrijksrelaties/Wichmann) (Neth. 2010); L v. C, [2007] 3 H.K.L.R.D. 819 (H.K. Ct. App.); Amparo en Revisión 300/2012, Tercer Tribunal Colegiado en Materia Civil del Primer Circuito [TCC] [Third Collegiate Civil Court of the First Circuit], Semanario Judicial de la Federación y su Gaceta, Décima Época, tomo III, Marzo de 2013, Página 1908 (Mex.); Amparo Directo 799/2008, Tercer Tribunal Colegiado en Materia de Trabajo del Cuarto Circuito [TCC] [Third Collegiate Court on Labor for the 
as a basis for not according CEDAW greater normative weight. ${ }^{50}$ But my findings challenge how far it is generally the case that courts are more likely to advance alternative interpretations of CEDAW where it is considered as legally binding, which indicate that no clear difference in citation and engagement appears to track legal status. Something more complex appears to be occurring.

\section{CEDAW as Law}

There is an important distinction in practice between CEDAW being the ground for direct legal claims in domestic courts and CEDAW being accorded indirect weight in the interpretative context. In the latter context, when it is accorded indirect effect, the court will be more likely to be convinced of the appropriateness of the content of the norm that CEDAW incorporates, ${ }^{51}$ or from the degree of international consensus for the need for change in particular areas that CEDAW represents, ${ }^{52}$ than by CEDAW's legal status, given that CEDAW is not legally binding in that context. This can be seen most clearly, perhaps, in those cases in which the court

Fourth Circuit], Semanario Judicial de la Federación y su Gaceta, Novena Época, tomo XXIX, Febrero de 2009, Página 2035 (Mex.).

${ }^{50}$ Police v. Apelu, W.S.S.C. 178 (Samoa 2010) (court rejected counsel's use of CEDAW to limit the harshness of the criminal law); Magaya v. Magaya, 3 LRC 35 (Sup. Ct. Zim. 1999) (Constitution protects the discriminatory aspects of customary law, CEDAW notwithstanding).

${ }^{51}$ CEDAW is apparently being used for normative purposes rather than for its legal authority in the following cases: Rajapaksha v. Attorney General, SBHC 189 (Solom. Is. 2011); Balelala v. State, (2004) FJCA 49 (Ct. App. Fiji I.) (CEDAW “adds weight”); Nález Ústavního soudu ze dne 28.02.2012 (ÚS) [Decision of the Constitutional Court of February 28, 2012], sp.zn. Pl.ÚS 26/11 (Czech) (development of recommendations to the Government, even in the absence of violation of CEDAW); Mojekwo v. Ejikeme, [2000] 5 NWLR 402 (C.A.) (Nigeria) (customary law affecting rights of female family members inequitable); Chan v. Canada, [1995] 3 S.C.R. 593 (Can.); Boureslan v. Aramco, 857 F.2d 1014 (5th Cir. 1988) (CEDAW regarded as relevant even though not ratified by the Senate); Gratz v. Bollinger, 539 U.S. 244 (2003) (Ginsburg, J., dissenting) (using CEDAW to support a particular interpretation of U.S. law-no sense of legal obligation); Grutter v. Bollinger, 539 U.S. 306, (2003) (Ginsburg, J., concurring); R. (Khan) v. Oxfordshire County Council, [2002] EWHC 2211 (Admin) (Eng.) (importance of domestic violence reflected in CEDAW); Mapingure v. Minister of Home Affairs, ZWSC 22 (Zim. Sup. Ct. 2014) (referring to CEDAW, inter alia: "it is both proper and instructive to have regard to them as embodying norms of great persuasive value in the interpretation and application of our statutes and the common law.").

52 See Putusan No. 22-24 PUU-VI/2008 (Const. Ct. Rep. Indon. 2008) (CEDAW's support for affirmative action as representing developing international opinion and as a positive development); Rono v. Rono \& Another, supra note 42 (Kenya "was moving in tandem with emerging global culture, particularly on gender issues" in adopting CEDAW); Fisher v. I.N.S., 79 F.3d 955 (9th Cir. 1996) (Noonan, J., dissenting) (arguing that Title VII should be interpreted as having extra-territorial effect on U.S. employers abroad, so that the United States will be respected). So too, CEDAW is seen as evidence of changing times: Rajapaksha v. Attorney General, supra note 51; Romualdez-Marcos v. Commission on Elections, supra note 49; Constitutional Court [Const. Ct.], 97Hun-Ka12, Aug. 31, 2000, (12-2 KCCR 167) (S. Kor.); State v. Bechu, FJMC 3 (Fiji 1999); Amparo en Revisión 300/2012, supra note 49; L v. C, supra note 49; Corte Constitucional [C.C.] [Constitutional Court], septiembre 13, 2012, Sentencia C-715-12, at http://www.corteconstitucional.gov.co/RELATORIA/2012/C-715-12.htm (Colom.) (changing approach to definition of domestic violence); Attorney-General (WA) v Marquet [2003] HCA 67 (Austl.) (CEDAW evidence of changing electoral practices and extension of franchise); Fornah v. Sec'y of State for the Home Dep't, [2007] 1 A.C. 412, 459 (appeal taken from Eng.) (U.K.) ("In other words, the world has woken up to the fact that women as a sex may be persecuted in ways which are different from the ways in which men are persecuted and that they may be persecuted because of the inferior status accorded to their gender in their home society"); Hariharan v. Reserve Bank of India, supra note 44 (" . . . the cry for equality and equal status . . . is not restrictive to any particular country" as is "amply demonstrate[d]" by CEDAW). 
draws on CEDAW as the basis for persuading (as opposed to requiring) the legislature to address a particular social problem identified by the court. ${ }^{53}$

The temptation is to view these "indirect effect" uses of CEDAW as domestic courts using CEDAW as the basis for moral and political authority rather than legal authority. But that would be to miss an important dimension of the domestic use we can observe from the cases. It is important that CEDAW is not just a set of international norms, but that it is a set of international legalnorms. It is because of the international legal status of CEDAW that it has this persuasive (even moral) value; were it not "law," it would not have this value, not least because there would be legitimate questions as to why it is that an advocate before the court is drawing attention to it, or that the court should be paying any attention to it. ${ }^{54}$ In other words, CEDAW is valuable in the domestic context because it is law, as well as because it is international, even though CEDAW may not be binding law in the jurisdiction concerned, grounding domestic subjective legal rights in that jurisdiction.

\section{Dialogic Approaches to Interpreting CEDAW}

A relatively strict dichotomy exists between two approaches adopted by the domestic judiciary: either the approach adopted is one where the domestic court regards the interpretation of CEDAW in that jurisdiction as a matter for the domestic court itself or it adopts a deferential approach, according considerable weight to the interpretation of CEDAW by other actors, national and international. What is striking is that a third, more "dialogic" engagement with foreign domestic courts, is not to be found. A dialogic approach is one in which the domestic court considers that it shares interpretative space with one or more other bodies, and the domestic court's role is to engage in some form of dialogue or conversation with other bodies in order to arrive at the meaning of CEDAW in the domestic context-for example, engaging in dialogue with domestic courts in other jurisdictions about the interpretation of CEDAW, an approach that is much beloved of much recent comparative constitutional law scholarship that examines judicial interpretation of domestic constitutional rights.

\footnotetext{
53 See, e.g., Tribunal Constitucional del Perú [TC] [Constitutional Court of Peru] Nov. 9, 2007, Gaceta Constitucional, tomo II, febrero de 2008, página 89 (Peru) (CEDAW mentioned as one of several relevant international instruments, but used more as a basis for criticising the legislature than as justification for finding for the plaintiff); Sapana Pradhan v. Prime Minister, Writ No. 064-WS-0011 of 2065 (S. Ct. Nepal 2008) (rather than declaring the provision ultra vires, the Court took a pragmatic approach and issued a directive order to the Prime Minister and to the Council of Ministers asking them to see that the provisions are consistent with CEDAW); Dhungana v. Nepal, Writ No. 3392 of 2050, 6 N.K.P. 2052 at 462 (S. Ct. Nepal 1993). In Dhungana, the Forum for Women, Law and Development, citing CEDAW (which had the status of national law in Nepal), asked the Supreme Court of Nepal to overturn a law that gave preference to males regarding ancestral property inheritance. Instead of striking down this law directly, the Court ordered the government to pass legislation within one year to rectify the situation. See also Pant v. Nepal government, Writ No. 917 of 2064, 138 I.L.R. 500 (S. Ct. Nepal 2007) (ordering the establishment of a government committee to study same-sex marriage, taking into account experience in other countries, and an analysis of international human rights instruments).

${ }^{54}$ See Austl. Competition and Consumer Comm'n v P. T. Garuda Indonesia (No. 9) [2013] FCA 323, II 47 (Austl.) (treating international law as law was essential in order "to accept its inherent legal nature, its domestic legal consequences, the practicality of it being dealt with as legal material and the qualification of domestic courts to engage in such an exercise. These matters mark it out as qualitatively different to foreign law.") There are contrasting examples, however, where the Court clearly emphasizes the international aspect of norms rather than their international legal aspect, for example, citing CEDAW and the Bejing Declaration together: Hariharan v. Reserve Bank of India, supra note 44; Apparel Export Promotion Council v. A. K. Chopra (1999) 1 S.C.C. 759 (India); Vishaka v. State of Rajasthan, (1997) 6 S.C.C. 241 (India).
} 
For Goodman and Jinks, the key issue is the identification of the patterns of "acculturation" 55 that enable this to happen. In this context, a key element in the explanation that these scholars have developed is the role that networks play in influencing these decisions. So, for example, a decision by a state to ratify a human rights treaty appears to be significantly affected by whether that state is a member of networks of other states which have ratified this treaty, even when the network of which these states is a member has little to do with human rights. They thus stress the idea of "socialization" 56 as the method by which states internalize these norms to the extent that they ratify these covenants.

Recent scholarship has argued that courts and judges at the national level are also increasingly engaging in conversation with each other, particularly in the context of rights claims, and that this judicial conversation takes place in part in formal and informal networks and in part by engaging with each other's opinions and decisions in the course of their judgments. ${ }^{57}$ So, we might expect the U.K. Supreme Court to cite and discuss relevant cases from the U.S. Supreme Court, for example, when discussing an issue of freedom from discrimination.

We might expect, more generally, that an equivalent type of transnational judicial dialogue is taking place in the interpretation of international law by national judges, where national judges refer to each other's interpretation of the international standard. If it is indeed the case that there is a significant dialogue among domestic courts about the interpretation of domestic constitutions (including sex discrimination provisions), it is puzzling why so little dialogue about how to interpret CEDAW appears to be occurring. One might have supposed that the opposite would be the case: if states are parties to the same treaty, they would want to see how other courts interpret it, ${ }^{58}$ not least so as to follow the requirement in the Vienna Convention on the Law of Treaties ${ }^{59}$ to look at subsequent practice. There are, of course, few provisions regarding whether courts may look to comparative jurisprudence in the interpretation of constitutional provisions. ${ }^{60}$

\footnotetext{
${ }^{55}$ Ryan Goodman \& Derek Jinks, How to Influence States: Socialization and International Human Rights Law, 54 DUKE L.J. 621 (2004).

${ }^{56} \mathrm{Id}$. at 630.

57 There is significant support for such a hypothesis. See, e.g., SLAUGHTER, A NEW WORLD ORDER, supra note 32, at 65-103; Slaughter, Global Community, supra note 32; Slaughter, Judicial Globalization, supra note 32; Slaughter, Typology, supra note 32. For examples of such a practice in particular areas, see Guy S. Goodwin-Gill, The Search for the One, True Meaning . . . in THE Limits of TransNaTiOnAL LAW: REFUGEE LAW, POLICY HARMONIZATION AND JUDICIAL DIALOGUE IN THE EUROPEAN UNION 204, 218 (Guy S. Goodwin-Gill \& Hélène Lambert eds., 2010) (refugees); Benvenisti, supra note 9, at 252 (phenomenon discernible in three areas: the judicial review of global counterterrorism measures, the protection of the environment in developing countries, and the status of asylum seekers in destination countries); see also August Reinisch. The International Relations of National Courts: A Discourse on International Law Norms on Jurisdictional and Enforcement Immunity, in THE LAW OF INTERNATIONAL RELATIONS: LIBER AMICORUM HANSPETER NEUHOLD 289, 293-97 (August Reinisch \& Ursula Kriebaum eds., 2007).

${ }^{58}$ See, e.g., Rosanne van Alebeek \& André Nollkaemper, The Netherlands, in THE PRIVILEGES AND IMMUNITIES OF INTERNATIONAL ORGANIZATIONS IN DOMESTIC COURTS 179, 205 (August Reinisch ed., 2013).

${ }^{59}$ Vienna Convention on the Law of Treaties arts. 31-33, opened for signature May 23, 1969, 1155 UNTS 331.

${ }^{60}$ But see S. AFr. CONST., 1996, $\$ 39$ (stating that courts “may consider foreign law" when interpreting the Bill of Rights).
} 
There appears to be evidence in practice to support this assumption, ${ }^{61}$ and some judges claim that this is what is occurring. ${ }^{62}$ So do several scholars. Linos has suggested that "international and domestic courts are typically faced with ambiguous treaty terms. To interpret them, they often turn to the jurisprudence of diverse foreign states." 63 Benvenisti has argued that "national courts often realize that they need to consider approaches adopted by other courts, foreign national courts or international courts. Unless there are significant reasons to deviate from the interpretation of international law by one national court, other courts are likely to follow it." ${ }^{64}$ And the assumption that such a development can be harnessed lies behind a key strategy of those in the UN system supporting the domestic implementation of CEDAW, ${ }^{65}$ but the trend goes well beyond Anglophone common law jurisdictions. ${ }^{66}$

None of these suggestions gains significant support from the study of the application of CEDAW in national courts. Benvenisti has suggested that "the logic of inter-judicial co-operation [in the interpretation of international law by domestic courts] has its limits," noting that it is not possible to trace such cooperation in the sphere of labor law, for example. ${ }^{67}$ It would appear that the interpretation of CEDAW is another example of the absence of such cooperation. Although there is some evidence of a (vertical) dialogue in the interpretation of CEDAW between states parties and the CEDAW Committee ${ }^{68}$ (though even this has been challenged ${ }^{69}$ ), there is practically no evidence of a (horizontal) dialogic interpretative approach to CEDAW in which courts engage with each other transnationally in a cooperative interpretative enterprise. $^{70}$ This is a puzzle.

${ }^{61}$ Examples outside the CEDAW context include, for example, Canadian cases citing foreign case law in decisions involving international law issues. See Michel Bastarache, The Globalisation of the Law and the Work of the Supreme Court of Canada, in HIGHEST COURTS AND GLOBALISATION 41, 49 (Sam Muller \& Sidney Richards eds., 2010).

62 See, e.g., Justice Ajit Prakash Shah, Judicial Globalisation: Supreme Court of India, in HIGHEST COURTS AND GLOBALISATION, supra note 61, at 67, 84 ("[T] he Indian Supreme Court has begun to see itself as an international court that is actively engaged in an international dialogue. It is not only looking out towards the international sphere for sources of obligations, but also access to other national jurisdictions for inspiration and guidance on the meaning and application of international norms.").

${ }^{63}$ Linos, supra note 38.

${ }^{64}$ Eyal Benvenisti \& Olga Frishman, Comparative Reasoning and the Democratization of International Law, in COMPARATIVE INTERNATIONAL LAW, supra note 1. An earlier article provides extensive examples in support of this proposition, as well as hypotheses why such cooperation takes place. See Eyal Benvenisti \& George W. Downs, Going Global to Preserve Domestic Accountability: The New Role of National Courts, in HIGHEST COURTS AND GLOBALISATION, supra note 61, at 163. See also JEREMY WALDRON, "PARTLY LAWS COMMON TO ALL MANKIND": FOREIGN LAW IN AMERICAN COURTS (2012).

65 See, e.g., BRINGING EQUALITY HOME, IMPLEMENTING THE CONVENTION ON THE ELIMINATION OF ALL FORMS OF DISCRIMINATION AGAINST WOMEN 18 (Ilana Landsberg-Lewis ed., 1998).

${ }^{66}$ Guy Canivet, Trans-judicial Dialogue in a Global World, in HIGHEST COURTS AND GLOBALISATION, supra note 61 , at 21 .

${ }^{67}$ Benvenisti \& Downs, supra note 64, at 181.

${ }^{68}$ Judith Resnik, Comparative (In)equalities: CEDAW, the Jurisdiction of Gender, and the Heterogeneity of Transnational Law Production, 10 INT'L J. CONST. L. 531, 544 (2012).

${ }^{69}$ Yvonne Donders \& Vincent Vleugel, Universality, Diversity and Legal Certainty: Cultural Diversity in the Dialogue between CEDAW and States Parties 36 (Amsterdam Law School Legal Studies, Research Paper No. 2014-40) ("In the practice of CEDAW, limited constructive interaction with the states parties takes place. Other than (sometimes) 'noting' or 'welcoming' some efforts by the state party, the Committee and the state party do not fully engage in a two-way dialogue").

${ }^{70}$ But see Jacomb v Austl. Mun. Admin. Clerical \& Services Union [2004] FCA 1250 (Austl.); Prakash v. Narayan [2000] FJHC 144 (Fiji) (High Court of Fiji referred to Indian and Australian court decisions in support of its use of international human rights instruments, including CEDAW); Vishaka v. State of Rajasthan, supra note 54 (Supreme Court of India similarly referred to an Australian court decision for the same reason). 


\section{What Domestic Functions Does CEDAW Fulfill in Domestic Courts?}

If what has been suggested so far is correct, that domestic jurisdictions sometimes need an international human rights law source to help address domestic issues, then explanations of some of the more puzzling patterns of resort to, and approaches to the interpretation of, CEDAW, and (as importantly) the absence of resort to CEDAW, may be forthcoming. Norms with an international source may be useful in some contexts and not in others. Whether the source of the norm being international is appealing to a domestic audience depends significantly on the local context. Different national histories suggest different functions for international human rights law, sometimes leading to different patterns of use and interpretation.

In Zimbabwe, even judges who were sympathetic to the use of international instruments tended not to cite CEDAW because to do so would be seen as threatening to a regime concerned to preserve national sovereignty. Interpretation of the local constitution and legislation is seen as a preferable way of addressing women's rights; the "principles in these [international] instruments are employed without direct acknowledgement."71 In the Netherlands, CEDAW's comparatively low rate of citation contrasts markedly with citation to other international human rights instruments, in particular the European Convention on Human Rights, which suggests that there is a rough hierarchy of international norms, with CEDAW relatively low down on the list, meaning that where issues can be addressed using other instruments, referring to CEDAW will be seen as unnecessary. ${ }^{72}$ So, too, the pattern of use of CEDAW in the United Kingdom may be best explained by the absence of other equivalent norms in the refugee area (because of the relatively weak application of the European Convention on Human Rights $[\mathrm{ECHR}]$ in this area).

In the Australian context, CEDAW plays a critical role in determining the constitutionality of federal sex discrimination legislation. The federal government's power to enact such legislation is based on it implementing international instruments ratified by Australia under the external affairs power. The scope of CEDAW thus determines the legitimate scope of domestic legislation, and therefore the interpretation of CEDAW becomes a critical issue for internal domestic legal reasons. ${ }^{73}$

\section{CEDAW as a Human Rights Convention}

Finally, when CEDAW is cited, it is often seen as not just a set of international legal norms but as a set of international human rights law norms. Courts are presented with CEDAW in this way because of the normative weight that presenting a claim to women's rights as a human rights

\footnotetext{
${ }^{71}$ Choice Damiso \& Julie Stewart, Zimbabwe and CEDAW Compliance: Pursuing Women's Equality in Fits and Starts, in WOMEN'S HUMAN RIGHTS, supra note 3, at 469.

${ }^{72}$ Marjolein van den Brink, The CEDAW After All These Years: Firmly Rooted in Dutch Clay?, in WOMEN'S HUMAN RIGHTS, supra note 3, at 495, 501.

${ }^{73}$ ABv Registrar of Births, Deaths and Marriages (2007) 162 FCR 528 (Austl.); Aldridge v Booth [1988] FCA 170 (Austl.); Hall v A. \& A. Sheiban Pty. Ltd. [1989] FCA 72 (Austl.); see also Andrew Byrnes, The Implementation of the CEDAW in Australia: Success, Trials, Tribulations and Continuing Struggle, in WOMEN's HuMAN RIGHTS, supra note 3 , at 323 .
} 
claim is presumed to have with the court, and courts may eventually be persuaded by this move. ${ }^{74}$

So too, judges appear to use the metaprinciple of "human dignity" as an articulated foundation for CEDAW because this enables the court to link the women's rights incorporated in CEDAW with other human rights instruments.

Human rights appear to have a normative weight that other international norms may not have because of their foundation in metaprinciples such as dignity. This understanding of human rights appears to be important to the interpretation of CEDAW at the domestic level not least because of the perception that human rights can present a fundamental challenge to a status quo that does not recognize adequately this understanding of the human person. CEDAW is thus referenced as evidence of changing times, and CEDAW is called on to add weight to a progressive interpretation of domestic legal rights. ${ }^{75} \mathrm{We}$ can see this particularly, for example, in the judgments of Baroness Hale in the United Kingdom, where CEDAW is presented as of importance because of the changed mind-set towards the position of women that it embodies. ${ }^{76}$ In the Indian context, the greater use of CEDAW in the employment context to challenge discrimination against women has been seen as part of the Indian Supreme Court's concern with globalization, in which "the employment of women [is] considered a necessary facet of national growth."77

There is little evidence that CEDAW has suffered from being tarred by domestic judges as the mere expression of Western liberal values that are of little relevance to countries elsewhere. On occasion, indeed, courts resist arguments that CEDAW should be adapted to local mores and norms, rather than the other way round..$^{78}$ On several occasions, judges have explicitly linked CEDAW with Islamic texts, in order to support both. ${ }^{79}$ So, too, the relative popularity of CEDAW in the East Asian and Pacific regions may be explainable in part by the absence of any regional source of equivalent norms, compared to the relative non-use of CEDAW in the area covered by the ECHR. In these and other contexts, an explanation drawing from the functions that CEDAW plays in the domestic context appears to "fit" better than others.

\footnotetext{
${ }^{74}$ In an Osaka High Court judgment (Osaka Saikō Saibansho, Sept. 26, 1991, no. 1884, 602 RŌDŌHANREI 72) the plaintiff referred to the Convention in these terms, but the Court did not address the issue. However, in a more recent case (Tōkyō Chihō Saibansho [Tōkyō Dist. Ct.] May 29, 2013, 2196 HANREI JiHō67; appealed to Tokyo High Court, Mar. 28, 2014 (not yet reported)), the Courts did consider whether a practice based on the Civil Code violated CEDAW. Although they denied the existence of the violation of the CEDAW, it would seem probable that the Court considered that CEDAW could no longer be ignored because of its status as a human rights norm. I am grateful to Akiko Ejima for this reference.

${ }^{75}$ Rajapaksha v. Attorney General, supra note 51; Romualdez-Marcos v. Commission on Elections, supra note 49; Constitutional Court [Const. Ct.], 97Hun-Ka12, supra note 52; State v. Bechu, supra note 52; Amparo en Revisión 300/2012, supra note 49; Hariharan v. Reserve Bank of India, supra note 44; L v. C [2007], supra note 49; Yemshaw v. Hounslow London Borough Council, [2011] UKSC 3, [2011] 1 W.L.R. 433 (appeal taken from Eng.) (U.K.) (changing approach to definition of domestic violence); Attorney-General (WA) v Marquet, supra note 52.

${ }^{76}$ Fornah v. Sec'y of State for the Home Dep't, [2007] 1 A.C. 412, 459 (appeal taken from Eng.) (U.K.) ('In other words, the world has woken up to the fact that women as a sex may be persecuted in ways which are different from the ways in which men are persecuted and that they may be persecuted because of the inferior status accorded to their gender in their home society.").

${ }_{77}$ Madhu Mehra, India's CEDAW Story, in WOMEN'S HuMAN RIGHTS, supra note 3, at 385, 408.

${ }^{78}$ E.g., Pengadilan Tinggi Jakarta [PTJ] [Jakarta High Court], Putusan No. 651/PDT/1988/PT.DKI (Indon.).

79 E.g., Mehmood v. State (1999) PLD (Lahore) 494 (Pak.).
} 


\section{IS CEDAW DIFFERENT?}

To what extent is the analysis of this article generalizable beyond CEDAW? There is some evidence that CEDAW has features that mean that its implementation at the domestic level differs from other human rights treaties. ${ }^{80} \mathrm{We}$ cannot, in other words, assume that what holds true for CEDAW will hold true for domestic judicial approaches to other human rights conventions, let alone other international law beyond human rights. Daniel Hill has suggested that there is a need for "treaty-specific theory building," 81 and this caution in assuming that what is true for one human rights treaty will be true for all is a salutary warning. Without equivalent studies of the domestic judicial approach to other areas of international law, we enter into the realm of speculation as to whether similar patterns would be likely to be found more generally. I cannot draw any definitive conclusions in the absence of comparative empirical evidence, and it is one of the purposes of this article to stimulate the production of just such evidence.

My intuition, nevertheless, is that the trends we observe regarding CEDAW are, in general, likely to apply to other human rights treaties. I do not consider CEDAW to be so anomalous in the human rights context as to render the findings of this Article sui generis. Nevertheless, some features of other human rights regimes may mean that they will be differently regarded by domestic judges, if only in part. Future research may want to focus on (1) differences in how broad or narrow the subject matter of the treaty is, (2) how general or specific particular provisions are in terms of how much flexibility they leave for interpretation, and (3) how recent the treaty is, with older treaties perhaps needing to be adapted over time more than more recent treaties.

Apart from these, two potential differences are already apparent that might be investigated further in other contexts. First, one of the significant differences in practice between CEDAW and, for example, international refugee law is that the work of the Office of the UN High Commissioner for Refugees ${ }^{82}$ (and previously that of James Hathaway at the University of Michigan Law School ${ }^{83}$ ) in establishing and maintaining an authoritative database of domestic level refugee law judgments has made cross-citation of domestic cases using international refugee law

${ }^{80}$ Neil A. Englehart \& Melissa K. Miller, The CEDAW Effect: International Law's Impact on Women's Rights, 13 J. HUM. RTS. 22, 38 (2014) (CEDAW "appears to be something of an anomaly in the international human rights treaty regime."); id. at 23 (emphasizing the greater ambition of CEDAW, even when compared with other human rights treaties).

${ }^{81}$ Daniel W. Hill Jr., Estimating the Effects of Human Rights Treaties on State Behavior, 72 J. POL. 1161, 1172 (2010).

${ }^{82}$ REFWORLD, http://www.unhcr.org/refworld/category,LEGAL,,CASELAW,,0.html (last visited July 23, 2015) (this site, containing over 7,000 judicial decisions from a large number of jurisdictions, is maintained by the Office of the United Nations High Commissioner for Refugees).

${ }^{83}$ James Hathaway, About RefLaw, REFLAW, http://www.reflaw.org/reflaw (last visited July 23, 2015) ("The University of Michigan, in cooperation with the International Association of Refugee Law Judges, launched refugeecaselaw.org in 1999 to 'fill the void' at a time when the UNHCR did not operate a full caselaw database. Even after UNHCR's Refworld collection ultimately came to include refugee caselaw, its search interface was generally found to be inadequate to the needs of judges, lawyers, scholars and others who wished to be able to perform structured and targeted searches for cases of a specific type. In the result, refugeecaselaw.org was maintained alongside Refworld to facilitate such research. Following UNHCR's fundamental retooling of its caselaw collection, it became evident that there was no longer a need for refugeecaselaw.org to continue operating in its previous capacity."). 
much easier for domestic courts in that context than is the case with CEDAW, and unsurprisingly we find more use of foreign domestic cases in that context. ${ }^{84}$ Second, one might predict that one reason to expect there would be many cases citing the UN Convention on the Rights of Persons with Disabilities (CRPD), ${ }^{85}$ even though the Convention only came into force in 2008 , is that there are very active transnational NGOs whose aim is to use CRPD in domestic litigation. ${ }^{86}$

\section{CONCLUSION}

The investigation of the different functions of international human rights law at the domestic level defines the core of the study of "comparative international human rights law." The observable patterns of references to CEDAW in national-level courts could result, to a significant degree, from the combination of the four elements involved in comparative international human rights law: that it is international law; and that it concerns human rights; and that it is law; and that it is being applied domestically.

The first three elements combined offer domestic courts a set of norms that is consensusbased ("international") and purportedly universal ("human rights"), which courts and legal advocates are able to draw on ("law"), in order to help address domestic concerns, or escape from otherwise troublesome "domestic" constraints. Courts and advocates in different jurisdictions draw on such norms in order to address similar or different domestic constraints, and similarities or differences may therefore emerge between these different jurisdictions as to the meaning and scope of the human right in question as a result. The similar or different functions played in different jurisdictions by this set of four elements contribute to an explanation of similarities or differences in substantive interpretation at the national level that neither previous international law literature taken by itself, nor the scholarship of comparative human rights taken by itself, delivers.

I hope that these tentative explanations will be subject to rigorous testing in the future in this and other contexts. They will need to be tested against similar analysis of national level judgments of other international human rights treaties and customary international human rights law, before any broader conclusion about the role of international human rights in general can be drawn. There is some evidence that the implementation of CEDAW at the national level has particular attributes that may mean that the findings are not necessarily transferable to other international human rights contexts, let alone the judicial interpretation of international law beyond human rights. Nevertheless, the study highlights a role for domestic judicial use of international human rights standards that differs from orthodox interpretations, demonstrating the utility of a comparative international human rights analysis.

${ }^{84}$ William Duncan, Judicial Co-operation and Communication in the Context of the Hague Conventions, in HIGHEST COURTS AND GLOBALISATION (Sam Muller \& Sidney Richards eds., 2010) 59, 65 (noting how the free availability on the Internet of decisions by courts in jurisdictions party to the Hague Convention of 1980 on Child Abduction has facilitated transnational judicial dialogue).

${ }^{85}$ Convention on the Rights of Persons with Disabilities, opened for signature Mar. 30, 2007, 2515 UNTS 3.

${ }^{86}$ It is hoped that the results of a forthcoming study of the implementation of CRPD by Lisa Waddington and Anna Lawson may throw some greater light on this, and the other issues highlighted. 